\title{
In Vitro Antioxidant and Anti-Diabetic Potential of Gymnema Sylvestre Methanol Leaf Extract
}

\author{
Ibrahim, A., \\ Department of Biochemistry, Bayero University, P.M.B. 3011, \\ Kano-Nigeria. \\ Department of Biochemistry, Ahmadu Bello University, P.M.B. \\ 1044, Samaru, Zaria-Nigeria \\ Babandi, A., \\ Tijjani, A.A., \\ Murtala, Y., \\ Yakasai, H.M., \\ Shehu, D., \\ Babagana, $K$. \\ Department of Biochemistry, Bayero University, P.M.B. \\ 3011, Kano-Nigeria. \\ Umar, I. A. \\ Department of Biochemistry, Ahmadu Bello University, P.M.B. \\ 1044, Samaru, Zaria-Nigeria
}

Doi: 10.19044/esj.2017.v13n36p218 URL:http://dx.doi.org/10.19044/esj.2017.v13n36p218

\begin{abstract}
Some medicinal plants and their purified derivatives have demonstrated beneficial therapeutic potentials for many centuries. They have been reported to exhibit antioxidant activity, reducing the oxidative stress in cells and are therefore useful in the treatment of many human diseases, including diabetes and other non-communicable diseases. This study evaluated antioxidative activity and enzymatic (alpha-amylase and alphaglucosidase) inhibitory potentials of Gymnema sylvestre methanolic leaf extract (GSMLE) using standard methods. Phytochemical screening revealed the presence of alkaloids, tannins, saponins, steroids, terpenoids and flavonoids. The total phenolics and total flavonoids content in the extract were found to be $6.629 \pm 0.745(\mu \mathrm{g} / \mathrm{ml}$ of catechol equivalent) and $0.004 \pm 0.0012(\mu \mathrm{g} / \mathrm{ml}$ of quercetin equivalent) respectively. GSMLE was shown to have radical scavenging activity against DPPH (290.54 $\pm 39.72 \%)$, hydroxyl radical $(86.507 \pm 23.55 \%)$ and hydrogen peroxide $(45.25 \pm 25.23$ $\%)$. The level of SOD was significantly decreased in $\mathrm{H}_{2} \mathrm{O}_{2}$ induced and
\end{abstract}


$\mathrm{H}_{2} \mathrm{O}_{2}+$ extract induced when compared with normal control $(\mathrm{p}<0.05)$; the level of $\mathrm{GSH}$ was significantly increased in $\mathrm{H}_{2} \mathrm{O}_{2}$ induced control and significantly decreased in $\mathrm{H}_{2} \mathrm{O}_{2}+$ extract induced test when compared to normal control. GSH was also decreased significantly in $\mathrm{H}_{2} \mathrm{O}_{2}$ +extract induced when compared to $\mathrm{H}_{2} \mathrm{O}_{2}$ induced control $(\mathrm{p}<0.05)$. The extract also demonstrated significant inhibition of alpha-glucosidase (IC50 182.26 $\pm 1.05 \mu \mathrm{g} / \mathrm{ml}$ ) when compared with standard acarbose ( $\left.\mathrm{IC}_{50} 189.52 \pm 0.46\right)$ and was more potent than the arcarbose on alpha-amylase inhibition with $\mathrm{IC}_{50}$ of $195.3 \pm 4.40$ and $200.05 \pm 7.16$ respectively. These findings may therefore, stress the potentiality of using Gymnema sylvestre as a natural remedy for the management of type 2 diabetes.

Keywords: Antioxidant, Lipid peroxidation, GSH, Diabetes, Gymnema sylvestre, HPLC

\section{Introduction}

Plants have always been a prototypical source of drugs. A wide array of botanicals and plant derived active chemical compounds has demonstrated activity consistent with their possible use in the treatment of several diseases over much of human history (Grover et al., 2002; Petrovska, 2012). These derivatives are widely available as food supplements in the market (EFSA, 2015).

Chronic non-communicable diseases such as diabetes are the number one causes of death and disability in the world (Lim et al., 2012). Diabetes mellitus (DM) is a metabolic disorder characterized by hyperglycemia resulting from defective insulin secretion, resistance to insulin action or both (Jarald et al., 2008; Khan et al., 2012). DM is a widespread disease, associates with chronic micro- and macro-vascular complications (Goycheva et al., 2006).

It has been demonstrated that about $5 \%$ of the inhaled oxygen is converted to reactive oxygen species (ROS), which consist of free radicals such as superoxide $\left(\mathrm{O}_{2}^{-}\right)$, hydroxyl $(\mathrm{OH})$ nitric oxide (NO) and lipid peroxyl $\left(\mathrm{LOO}^{-}\right)$and non-free radical species like hydrogen peroxide $\left(\mathrm{H}_{2} \mathrm{O}_{2}\right)$, ozone $\left(\mathrm{O}_{3}\right)$ and lipid peroxide (LOOH) (Maxwell, 1995). This ROS produce oxidative stress and generate many pathophysiological disorders such as arthritis, inflammation, cancer and type 2 diabetes (Mandal et al., 2009; Odegaard et al., 2016). Oxidative stress is due to an imbalance between the free radical-generation and radical-scavenging capacities (Maritim et al., 2003; Yao et al., 2010). Antioxidants can act as free radical scavengers by preventing and repairing damages caused by ROS and therefore can enhance the immune defense and reduce the risk of degenerative diseases (Pham-Huy et al., 2008). It has been demonstrated that diabetic patients are under 
oxidative stress; the elevation of free-radical generation and decline in the antioxidant defense may partially mediate the beginning and progression of diabetes associated complications (Jin et al., 2008; Vos et al., 2012). Therefore, use of antioxidants can be beneficial for diabetic patients, not only to maintain antioxidants levels in the body but also to treat the long term complications that can arise (Iwai, 2008).

Hydrolysis of dietary carbohydrates such as starch is the major source of glucose in the blood. Pancreatic $\alpha$-amylase and intestinal $\alpha$-glucosidase are key enzymes at the initial stage in the digestion of starch, hydrolyzing the $\alpha-1,4$-glucoside linkages. The inhibition of these enzymes significantly decreases digestion and uptake of carbohydrates and lowers the postprandial blood glucose level in the non-insulin dependent diabetes mellitus patients (Fred-Jaiyesimi et al., 2009). Some antidiabetic drugs such as acarbose, miglitol and voglibose in current medical practice are used as $\alpha$-glucosidase and $\alpha$-amylase inhibitors. The main drawback of these drugs is their side effects especially the abdominal distention, bloating, meteorism, flatulence and in some cases, diarrhoea (Chakrabarti and Rajagopalan, 2002; Kimmel and Inzucchi, 2005). It has been suggested that these side effects might be caused by the excessive inhibition of the pancreatic $\alpha$-amylase, leading to the abnormal bacterial fermentation of undigested carbohydrates in the colon (Bischoff, 1994). Natural products which have been shown to possess a low inhibitory effect against $\alpha$-amylase and high inhibition activity against $\alpha$ glucosidase can be used as an effective means to reduce postprandial hyperglycaemia by inhibiting these enzymes in the intestines and thus, lowers carbohydrates absorption; with minimal adverse effects (Tarling et al., 2008; Kim et al., 2009; Shori, 2015). One of these medicinal plants used, is Gymnema sylvestre (Gurmar-sugar destroyer or killer; family: Asclepiadaceae). Even though, several studies worldwide reported sugar inactivation and antidiabetic properties of Gymnema sylvestre (Li et al., 2015; Kamble et al., 2016). This study aimed to specifically determine inhibitory potential of carbohydrate hydrolyzing enzymes (alpha-amylase and alpha-glucosidase) and antioxidant activities of Gymnema sylvestre methanol leaves extract (GSMLE).

\section{Materials and Methods}

\section{Plant collection and Identification}

The leaves of Gymnema Sylvestre were collected from Filin Shagari, Bauchi State, Nigeria. It was identified at the herbarium unit of Biological sciences department, Bayero University Kano and voucher specimen no. BUKHAN0349 was deposited for future references. The leaves were shade dried and ground into smooth powder using a clean metal mortar and pestle. 
It was weighed using a weighing balance and kept in clean polythene nylon. The sample was used throughout the experiment.

\section{Preparation of Extract}

The GS leaves powder (40g) was dissolved in $200 \mathrm{ml}$ of methanol. The container was covered using an aluminum foil paper first followed by the container cover. After 48 hours, the mixture was filtered using a nylon sieve into the small container and the residue spread on a wide plastic plate and allowed to dry. The residue was re-extracted twice with fresh $200 \mathrm{ml}$ of methanol for 24 hours. The pooled and dried extract was subsequently used for this study.

\section{Animal Acquisition and Care}

Three (3) healthy rabbits and fifteen (12) mice (male and female) were procured from Sabon gari Market, Kano, and animal house, Bayero University, Kano (BUK)-Nigeria respectively. They were kept in metal cases at the animal house of the department of Biological Sciences, BUK. They were allowed to acclimatize for one week and given access to food and water ad-libitum following the method of Klein and Bayne (2007).The protocols of the study was according to international Test guidelines(TG407) (OECD, 2006) and also the National Institute of Health Guide for the care and use of laboratory animals (NIH, 1996).

\section{Animal (mice) Grouping}

The mice were randomly grouped $(n=3)$ into the following:

Group 1: Served as test group and received alloxan $(150 \mathrm{mg} / \mathrm{kg})+600 \mathrm{mg} / \mathrm{kg}$ GSEALE.

Group 2: Served as the normal control and received $10 \mathrm{ml} / \mathrm{kg}$ b.w water.

Group 3: Served as Diabetic control and received $150 \mathrm{mg} / \mathrm{kg}$ body alloxan only.

Group 4: Served as standard drug group and received $150 \mathrm{mg} / \mathrm{kg}$ alloxan +6 $\mathrm{mg} / \mathrm{kg}$ body weight of Glibenclamide.

Animals were anaesthetized with light ether anesthesia, after the experiment and blood sample was collected in EDTA containers.

\section{Induction of Diabetic model}

Mice were made diabetic by a single intraperitoneal (i.p.) injection of alloxan monohydrate, dissolved in normal saline at a dose of $150 \mathrm{mg} / \mathrm{kg} \mathrm{b.w} \mathrm{(Yanarday} \mathrm{and} \mathrm{Colae,} \mathrm{1998).} \mathrm{The} \mathrm{plasma} \mathrm{glucose} \mathrm{level} \mathrm{of}$ each mouse was determined by tail vein puncture method using Glucometer. Mice with a fasting plasma glucose range between $250-300 \mathrm{mg} / \mathrm{dL}$ were considered as diabetic. 


\section{Preparation of Rabbit Liver Slices}

The rabbit liver was obtained fresh after the animal decapitation, plunged into cold sterile phosphate buffer saline, thin slices of $1 \mathrm{~mm}$ was cut using a sterile scalpel and maintained freeze till use.

\section{Qualitative Phytochemical Analyses}

Molisch's test of carbohydrates, monoscharrides, free reducing sugars, combined reducing sugars, anthraquinones, steroids, terpenoids and saponins were carried out as outlined by Sofowora (1993) Method. Test for tannins and flavonoid was by Trease and Evans (2002). Soluble Starch was tested by Vishnoi (1979) Method. Each of the tests was qualitatively expressed as negative (-) or positive (+)

\section{Quantitative analysis on phytochemical constituents}

\section{Saponins (Obadoni andOchuko, 2001)}

$2 \mathrm{~g}$ sample in conical flask was mixed with $20 \mathrm{ml} 20 \%$ Ag Ethanol there was no color change then the solution was heated $\left(55^{\circ} \mathrm{C}\right)$ for 1 hours with stirring continuously. When taken into the water bath the color changes from pale green to green. Then filtered and residue re-extracted with further $20 \mathrm{ml}, 20 \%$ Ethanol. The extracts were combined and volume was reduced to $4 \mathrm{ml}$ over water bath at $90^{\circ} \mathrm{C}$. Concentrate was then transferred into $250 \mathrm{ml}$ separating funnel, Then extracted with $20 \mathrm{ml}$ diethyl ether and it was shaked vigorously it was then allowed to settle. Aqueous layer recovered the upper layer was further extracted.

Ether layer discarded the lower layer was discarded. To the last three times of the extracted layer there was addition of $30 \mathrm{ml} \mathrm{n}$-butanol (to the purified extracts). Then it was washed with $10 \mathrm{ml}, 5 \%$ aqueous sodium chloride two times. The extract was collected into a crucible (a $30 \mathrm{ml}$ crucible) which was weighed. The remaining solution was heated in the water bath. Then dry sample was evaporated in oven to constant weight.

\section{Flavonoids (Boham and Abyazan, 1974)}

$2 \mathrm{~g}$ of the leaf sample was repeatedly extracted with $20 \mathrm{ml}$ of $80 \%$ aqueous methanol at room temperature. The mixture was filtered using Whatman no.1 filter paper. The filtrate was transferred to crucible and evaporated to dryness over water bath and dried until constant weight.

\section{Alkaloids}

$2 \mathrm{~g}$ sample was added into $20 \mathrm{ml}$ of $10 \%$ Acetic Acid in Ethanol (in $250 \mathrm{ml}$ beaker). The mixture was covered and was allowed to stand for 1hour. After the hours the mixture was filtered. The extract was then concentrated in water bath at $60^{\circ} \mathrm{C}$ to one-fourth of its volume $\left(\frac{1}{4}\right)$. Concentrated 
Ammonium Hydroxide was then added drop-wise till precipitation is complete. The solution was allowed to settle and the precipitate was collected. The precipitate was then washed with dilute ammonium hydroxide and filtered. The residue was finally dried to constant mass.

\section{Tannins/Pseudotannins}

A) $5 \mathrm{ml}$ sample was put into stoppered conical flask then $25 \mathrm{ml} 0.1 \mathrm{~N}$ iodine was added into the stoppered conical flask followed by the addition of $4 \% \mathrm{NaOH} 10 \mathrm{ml}$ and kept in the dark for 1 hour. After the hour the colorless solution was acidified with $10 \mathrm{ml}$ of $4 \% \mathrm{H}_{2} \mathrm{SO}_{4}$. Upon addition of $10 \mathrm{ml}$ of $4 \% \mathrm{H}_{2} \mathrm{SO}_{4}$ the color changes to red. The mixture was then titrated with $0.1 \mathrm{~N}$ sodium thiosulphate and starch solution acting as the indicator.

Blank experiment (A) was carried out using distilled $\mathrm{H}_{2} \mathrm{O}$ instead of the plant sample. All reagents were added to the blank on addition of $4 \%$ $\mathrm{NaOH} 10 \mathrm{ml}$ the color changes to yellow. On addition to $10 \mathrm{ml}$ of $4 \% \mathrm{H}_{2} \mathrm{SO}_{4}$ the color changes to dark brown.

Titrate value $=$ Tannis $\&$ psuedotannins $(\mathrm{A})$

B) $5 \mathrm{ml}$ sample was put into another stoppered conical flask $15 \mathrm{ml}$ of $1 \%$ gelatin was added and $25 \mathrm{ml}$ of $0.1 \mathrm{~N}$ iodine was added into volumetric flask, the mixture was mixed \& keep in the dark for 1hour. The mixture was then diluted with $10 \mathrm{ml}$ distilled $\mathrm{H}_{2} \mathrm{O}$ and titrated with $0.1 \mathrm{~N}$ sodium thiosulphate solution with starch as indicator

Titre value $=$ pseudotannins only $(B)$

Blank experiment (B) was carried out using distilled $\mathrm{H}_{2} \mathrm{O}$ instead of the plant sample. On addition to all the reagents it turned brown.

\section{Total Phenolic (Pyrocatecholgallic acid) compounds}

$0.1 \mathrm{ml}$ extract (containing $1 \mathrm{mg}$ extract) was put into $100 \mathrm{ml}$ conical flask the volume was adjusted to $46 \mathrm{ml}$ with distilled $\mathrm{H}_{2} \mathrm{O}$. $0.5 \mathrm{ml}$ Folinciocaltean reagent was added and allowed to stand for 3 minutes followed by the addition of $3 \mathrm{ml} 2 \% \mathrm{Na}_{2} \mathrm{CO}_{3}$. The mixture was then shaked on a shaker for 1 hour at room temperature. After the shaking absorbance was then measured at $760 \mathrm{~nm}$.

\section{Total Flavonoid}

$2 \mathrm{ml}$ of $2 \% \mathrm{AlCl}_{3}$ in methanol was added unto $0.1 \mathrm{ml}$ extract $(0.1 \mathrm{mg} / \mathrm{ml})$ and was kept for 10 minutes. The absorbance was then taken at $415 \mathrm{~nm}$ which was read against a blank. Blank sample contains $2 \mathrm{ml}$ extract and $2 \mathrm{ml}$ methanol.

\section{Quantitative Phytochemical Analyses}

Determination of saponins and alkaloids by Sofowora (1993); flavonoids and tannins/pseudotannins by Trease and Evans (2002); total 
phenolic (pyrocatechol gallic acid) Compounds (Mallick and Singh, 1980) and total flavonoid by Cameron et al. (1943).

\section{High Performance Liquid Chromatography (HPLC) of Gymnema sylvestre Methanol Leaves Extract (Gupta et al., 2012)}

The following methodology was used for obtaining the chromatogram of extract and five different standards; resorcinol, gallic acid, catechol, quercetin and saponin white. High Performance Liquid Chromatography (HPLC) analysis was performed using a Shimadzu LC20A System with Shin-pack VP-OSD $(150 \mathrm{~mm} \times 4.6 \mathrm{~mm}$ i.d $5 \mu \mathrm{m}$ column $)$ and LCsolution software. Five (5) $\mathrm{mg}$ of each standard compound and $0.5 \mathrm{mg}$ of the extract were dissolved in $10 \mathrm{ml}$ of HPLC grade methanol resulting in a sample concentration of $500 \mu \mathrm{g} / \mathrm{ml}$. This was sonicated and then passed through Whatman Nylon Membrane Filter $(0.45 \mu \mathrm{m}$ and $47 \mathrm{~mm}$ diameter) before injecting it in the column. In general, it was found that UV detection was quite pronounced at wavelength range: 190 to $700 \mathrm{~nm}$ Bandwidth at 8 nm Wavelength accuracy: $1 \mathrm{~nm}$ max.

1. Total run time was 22 minutes

2. Gradient elution of two solvents was used- Solvent A (Acetonitrile) and Solvent B (Methanol (1:25)) (Gupta et al., 2012). The gradient program was begun with $100 \% \mathrm{~B}$ and was held at this concentration for the first 4 minutes. This was followed by $50 \%$ eluent $\mathrm{A}$ for the next 6 minutes after which concentration of $\mathrm{A}$ was increased to $80 \%$ for the next 10 minutes and then reduced to $50 \%$ again for the following 2 minutes.

\section{DPPH Spectrophotometric Assay}

The scavenging ability of the natural antioxidants of the leaves towards the stable free radical DPPH was measured by the method of Mensor et al. (2001).

An extract solution with $0.1 \mathrm{mg} / \mathrm{ml}$ was prepared by dissolving $0.1 \mathrm{~g}$ of the dried extract in $10 \mathrm{ml}$ of methanol. $0.5 \mathrm{ml}$ of methanolic solution of DPPH was taken using $1 \mathrm{ml}$ pipette and transferred into a test tube. $0.48 \mathrm{ml}$ of methanol was added followed by the addition of $20 \mu \mathrm{L}$ of the extract. The mixture was allowed to react at room temperature for 30 minutes. The test was performed 3 times. Methanol was used as blank and DPPH in methanol without the leaf extract was used as positive control. After the incubation, the discoloration of purple color was measured at $518 \mathrm{~nm}$ using a spectrophotometer. The test was carried out 3 times.

\section{Calculation}

The radical scavenging activity was calculated as follows:

Scavenging activity $\%=\underline{\mathrm{A}_{518}}$ (sample) $-\mathrm{A}_{518}$ (blank) $\times 100$

$$
\text { A518 (blank) }
$$




\section{Hydrogen Peroxide Scavenging Effects}

The ability of the extracts to scavenge hydrogen peroxide was assessed by the method of Ruch et al. (1989). A solution of $\mathrm{H}_{2} \mathrm{O}_{2}(40 \mathrm{mM})$ was prepared in phosphate buffer. $0.6 \mathrm{ml}$ of $\mathrm{H}_{2} \mathrm{O}_{2}$ solution was taken using $1 \mathrm{ml}$ pipette and transferred into a test tube. $10 \mu \mathrm{l}$ of extract was added and the total volume was made up to $3 \mathrm{ml}$ with phosphate buffer. The absorbance of the reaction was measured at $230 \mathrm{~nm}$ in a spectrophotometer. The test was performed 3 times. Phosphate buffer without $\mathrm{H}_{2} \mathrm{O}_{2}$ was used as blank. The test was carried out 3 times

\section{Calculation}

The extent of $\mathrm{H}_{2} \mathrm{O}_{2}$ scavenging of the leaf extract was calculated as:

$\%$ scavenging of hydrogen peroxide $=\underline{\left(\mathrm{A}_{0}-\mathrm{A}_{1}\right)} \times 100$

$\mathrm{A}_{0}$

Where: $A_{0}-$ Absorbance of control; $A_{1}-$ Absorbance in the presence of leaf extract

\section{Measurement of Hydroxyl Radical Scavenging Activity}

The extent of hydroxyl radical scavenging from Fenton reaction was quantified using 2- deoxyribose oxidative degradation as described by Elizabeth and Rao (1990) with modification; where phosphate buffer was used instead of $\mathrm{KH}_{2} \mathrm{PO}_{4}-\mathrm{KOH}$ buffer.

$0.1 \mathrm{ml}$ of deoxyribose, $0.1 \mathrm{ml}$ of $\mathrm{FeCl}_{3}, 0.1 \mathrm{ml}$ of EDTA, $0.1 \mathrm{ml}$ of $\mathrm{H}_{2} \mathrm{O}_{2}, 0.1 \mathrm{ml}$ of Ascorbate, $0.1 \mathrm{ml}$ of phosphate buffer and $20 \mu \mathrm{l}$ of plant extract were added in a test tube and the volume was made to $1 \mathrm{ml}$ with distilled water. The mixture was incubated at $37^{\circ} \mathrm{C}$ for 1 hour. At the end of the incubation, $1.0 \mathrm{ml}$ of TBA was added and heated at $95^{\circ} \mathrm{C}$ for 20 minutes. After cooling, the TBARS formation was measured spectrophotometrically at $532 \mathrm{~nm}$ against appropriate blank. $\mathrm{H}_{2} \mathrm{O}_{2}$ was used as positive control. The test was performed 3 times.

\section{Calculation}

$$
\text { Scavenging activity } \%=\frac{\mathrm{A}_{518}(\text { sample })-\mathrm{A}_{518}(\text { blank })}{\mathrm{A}_{518}(\text { blank })} \times 100
$$

\section{Estimation of Reduced Glutathione} (1979).

Reduced glutathione was determined by the method of Moron et al.

Standard GSH corresponding to concentrations ranging between 2 and 10 nmoles was prepared. $0.1 \mathrm{ml}$ of each concentration was taken in a test tube and made up to $1.0 \mathrm{ml}$ with $0.2 \mathrm{M}$ sodium phosphate buffer. $2.0 \mathrm{ml}$ of freshly DTNB solution was added and the intensity of the yellow colour 
developed was measured in a spectrophotometer at $412 \mathrm{~nm}$ after 10 minutes was taken for 180 seconds after 30 seconds each. The analysis was carried out in triplicate analysis.

\section{Assay of Catalase (CAT, EC 1.11.1.6)}

Catalase activity was assayed using the method of Luck (1974).

$3.0 \mathrm{ml}$ of $\mathrm{H}_{2} \mathrm{O}_{2}$-phosphate buffer was taken in a test tube, $40 \mu \mathrm{l}$ of enzyme extract was added rapidly and it was mixed thoroughly. The assay was carried out in triplicate analysis.

One enzyme unit was calculated as the amount of enzyme required to decrease the absorbance at $240 \mathrm{~nm}$ by 0.05 units.

\section{Assay of Superoxide Dismutase (SOD, EC 1.15.1.11)}

SOD was assayed according to the method of Kakkar et al (1984) with modification. 0.1 M Phosphate buffer $(\mathrm{pH} 7.4)$ was used instead of $0.025 \mathrm{M}$ sodium pyrophosphate buffer $(\mathrm{pH} 8.3$ ) and potassium phosphate buffer (50mM, pH 6.4).

a) Extract Treated alone: $0.5 \mathrm{~g}$ of methanol leaf extract was dissolved in $10 \mathrm{ml}$ phosphate buffer and $0.5 \mathrm{~g}$ of the liver slices was ground with the $5 \mathrm{ml}$ dissolved solution. The mixture was filtered and centrifuged at 2000rpm for 10 minutes the supernatant was filtered with a sieve and centrifuged for the second time to obtain supernatant. The liver assay mixture contained $1.2 \mathrm{ml}$ phosphate buffer, $0.1 \mathrm{ml}$ of $\mathrm{PMS}, 0.3 \mathrm{ml}$ of $\mathrm{NBT}, 0.2 \mathrm{ml}$ of the supernatant and water was used to make a total volume of $2.8 \mathrm{ml}$. The reaction was initiated by the addition of $0.2 \mathrm{ml}$ of NADH. The mixture was incubated at $30^{\circ} \mathrm{C}$ for 90 seconds. The reaction was arrested by the addition of $1.0 \mathrm{ml}$ of glacial acetic acid. The mixture was shaken with $4.0 \mathrm{ml}$ of $\mathrm{n}$ butanol, allowed to stand for 10minutes and the mixture was centrifuged.

b) $\mathrm{H}_{2} \mathrm{O}_{2}$-Extract Treated: $1.0 \mathrm{ml}$ of $\mathrm{H}_{2} \mathrm{O}_{2}$-phosphate buffer and $5.0 \mathrm{ml}$ of the dissolved extract was ground with $0.5 \mathrm{~g}$ of liver slices. The solution was filtered and centrifuged at 2000rpm for 10 minutes. The liver assay mixture contained $1.2 \mathrm{ml}$ phosphate buffer, $0.1 \mathrm{ml}$ of PMS, $0.3 \mathrm{ml}$ of NBT, $0.2 \mathrm{ml}$ of the supernatant and water was used to make a total volume of $2.8 \mathrm{ml}$. The reaction of was initiated by the addition of $0.2 \mathrm{ml}$ of $\mathrm{NADH}$. The mixture was incubated at $30^{\circ} \mathrm{C}$ for 90 seconds. The reaction was arrested by the addition of $1.0 \mathrm{ml}$ of glacial acetic acid. The mixture was shaken with $4.0 \mathrm{ml}$ of n-butanol, allowed to stand for 10 minutes and the mixture was centrifuged. The intensity of the chromagen in the butanol layer was measured at 560nm in a spectrophotometer after each 30 seconds for 180 seconds. The analysis was carried out in triplicate. 


\section{Estimation of Lipid Peroxidation (LPO) In Rat Liver Slices}

The extent of LPO in rabbit liver slices was estimated by the method described by Nichans and Samuelson (1968). a) Extract Treated: $0.5 \mathrm{~g}$ methanol leaf extract was dissolved in $10 \mathrm{ml}$ phosphate buffer and $0.5 \mathrm{~g}$ of the liver slices was ground with the $5 \mathrm{ml}$ dissolved solution. $1.0 \mathrm{ml}$ of homogenate was added to $2.0 \mathrm{ml}$ of $\mathrm{TBA}-\mathrm{TCA}-\mathrm{HCl}$ reagent. The contents were incubated in a boiling water bath for 15 minutes.

b) $\mathrm{H}_{2} \mathrm{O}_{2}$-Extract Treated: $0.5 \mathrm{~g}$ was ground with liver slices $1.0 \mathrm{ml}$ of $\mathrm{H}_{2} \mathrm{O}_{2}$-phosphate buffer and $5.0 \mathrm{ml}$ of the dissolved extract. $1.0 \mathrm{ml}$ of homogenate was added to $2.0 \mathrm{ml}$ of TBA-TCA-HCl reagent. The contents were incubated in a boiling water bath for 15 minutes. The pink colour developed was estimated at $535 \mathrm{~nm}$ against a reagent blank in a spectrophotometer.

\section{In-vitro $\alpha$-Amylase and $\alpha$-Glucosidase Inhibition Assay}

The $\alpha$-amylase and $\alpha$-glucosidase inhibitory activities were determined according to the method described by Kim et al. (2000) and Jung et al. (2006).

For $\alpha$-glucosidase inhibition, yeast $\alpha$-glucosidase was dissolved in $100 \mathrm{mM}$ phosphate buffer $(\mathrm{pH} 7.0)$, containing bovine serum albumin 2 $\mathrm{mg} / \mathrm{mL}$ and sodium azide $0.2 \mathrm{mg} / \mathrm{mL}$ which was used as an enzyme source. Paranitrophenyl- $\alpha$-D-glucopyranoside was used as substrate. Samples were weighed and serial dilutions of $4,8,15$ and $20 \mathrm{mg} / \mathrm{ml}$ were made up with equal volumes of dimethylsulfoxide and distilled water. $10 \mu \mathrm{l}$ of extract dilutions was incubated for 5 minutes with $50 \mu 1$ of enzyme source. After the incubation, $50 \mu \mathrm{l}$ of the substrate was added and further incubated for 5 minutes at room temperature. The pre-substrate and post-substrate addition absorbance was measured at $405 \mathrm{~nm}$. The increase in absorbance on substrate addition was obtained. Each test was performed three times and the mean absorption was used to calculate percentage $\alpha$-glucosidase inhibition. For $\alpha-$ amylase inhibition assay, the enzyme porcine pancreatic amylase and substrate paranitrophenyl- $\alpha$-D-maltopentoglycoside were used. Acarbose was used as positive control with various concentrations 4, 8, 15 and 20 $\mathrm{mg} / \mathrm{ml}$. Percentage $\alpha$-glucosidase inhibition was calculated according to the following formula (Jung et al., 2006).

\section{Statistical Analysis}

$$
\text { Percentage of inhibition }=\frac{[(\text { control } 405-\text { extract } 405)] \times 100}{\text { Control } 405}
$$

Data are presented as means \pm SEM. Comparison between the means was done using student t-test, $\mathrm{p}<0.05$ considered significant using SPSS Statistics 17.0 version. Percentage change of glucose level was calculated using Microsoft Excel. 


\section{Results}

Phytochemical screening carried on Gymnema sylvestre leaf revealed the presence of carbohydrates, free reducing sugar, tannins, steroids, terpenoids, saponins, flavonoids, alkaloids and soluble starch as shown in table 1.

Table 1. Qualitative and Quantitative phytochemicals composition of Gymnema sylvestre methanol leaf extract

\begin{tabular}{lll}
\hline $\mathbf{S} / \mathbf{N}$ & Phytochemicals & Qualitative \\
\hline $\mathbf{1}$ & Carbohydrates & + \\
$\mathbf{2}$ & Monosaccharides & - \\
$\mathbf{3}$ & free reducing sugar & + \\
$\mathbf{4}$ & combined reducing sugar & - \\
$\mathbf{5}$ & Tannins & + \\
$\mathbf{6}$ & Anthraquinones & - \\
$\mathbf{7}$ & Steroids & + \\
$\mathbf{8}$ & Terpenoids & + \\
$\mathbf{9}$ & Saponins & + \\
$\mathbf{1 0}$ & Flavonoids & + \\
$\mathbf{1 1}$ & Alkaloids & + \\
$\mathbf{1 2}$ & Soluble starch & + \\
\hline
\end{tabular}

Present $=(+)$, absence $=(-)$.

Table 2: Quantitative Phytochemical Composition of Gymnema sylvestre Methanol Leaf

\begin{tabular}{ll} 
& Extract. \\
\hline PHYTOCHEMICALS & QUANTITATIVE (\%) \\
\hline Saponins & $62.98 \pm 0.42$ \\
Flavonoids & $0.61 \pm 0.05$ \\
Alkaloids & $15.43 \% \pm 0.17$ \\
Tannins & $12.12 \pm 0.23$ \\
\hline
\end{tabular}

The quantitative phytochemical analysis of Gymnema sylvestre shows highest composition of saponin with $62.98 \%$ and relatively low composition of flavonoids with $0.61 \%$ as shown in table 2 .

High performance liquid chromatography (HPLC) chromatograms of Gymnema sylvestre extract shows different values of retention times [(peak $1=2.688)$, (peak 2=3.39), (peak 3=5.644), (peak 4=9.150), (peak 5=10.984) and (peak 6=12.342)] when compared with 5 different standards $[($ catechol=3.259), $($ gallic acid=4.402), $($ resorcinol=3.421 $),($ quercetin=12.096) and (saponin white=2.862)] (Table 3).

Table 3: High performance liquid chromatography profile of Gymnema sylvestre methanolic leaf extract compared with some phenolic standards.

\begin{tabular}{cccccc} 
S/N & RT & COMPOUND & $\begin{array}{c}\text { MOLECULAR } \\
\text { WEIGHT }\end{array}$ & $\begin{array}{c}\text { MOLECULAR } \\
\text { FORMULAR }\end{array}$ & AREA\% \\
\hline $\mathbf{1}$ & 3.259 & Catechol & 110.10 & $\mathrm{C}_{6} \mathrm{H}_{6} \mathrm{O}_{2}$ & 100.00 \\
$\mathbf{2}$ & 4.402 & Gallic acid & 170.12 & $\mathrm{C}_{7} \mathrm{H}_{6} \mathrm{O}_{5}$ & 100.00 \\
$\mathbf{3}$ & 3.366 & G. slyvestre & - & - & 68.152 \\
\hline
\end{tabular}




\begin{tabular}{lccccc}
\hline \multicolumn{7}{c}{ 2.680 slyvestre } \\
$\mathbf{4}$ & 12.096 & Quercetin & 302.24 & $\mathrm{C}_{15} \mathrm{H}_{14} \mathrm{O}_{9}$ & 96.574 \\
$\mathbf{5}$ & 3.421 & Resorcinol & 110.10 & $\mathrm{C}_{6} \mathrm{H}_{6} \mathrm{O}_{2}$ & 100.00 \\
$\mathbf{6}$ & 2.862 & Saponin white & 414.00 & $\mathrm{C}_{27} \mathrm{H}_{42} \mathrm{O}_{3}$ & 53.369 \\
\hline
\end{tabular}

$$
\mathrm{RT}=\text { Retention Time }
$$

The radical scavenging activity of Gymnema sylvestre methanolic leaf extract was measured in \% inhibition. The extract was shown to have 29.05 $\pm 3.97 \mathrm{DPPH}, \quad 45.25 \pm 15.23 \quad \mathrm{H}_{2} \mathrm{O}_{2}$, and $86.51 \pm 13.55 \mathrm{OH}^{-}$radical scavenging activity. Total flavonoids and total phenolics were also found to be $6.63 \pm 0.75$ and $0.004 \pm 0.00 \mu \mathrm{g} / \mathrm{ml}$ respectively as shown in table 4 .

Table 4: Radical scavenging activity, Total phenolics and total flavanoids of Gymnema sylvestre methanolic leaf extract

\begin{tabular}{ccc}
\hline $\mathbf{S} / \mathbf{N}$ & Scavengers & Composition \\
\hline $\mathbf{1}$ & Total phenolic $(\mu \mathrm{g} / \mathrm{ml})$ & $6.63 \pm 0.75$ \\
\hline $\mathbf{2}$ & Total flavonoids $(\mu \mathrm{g} / \mathrm{ml})$ & $0.004 \pm 0.00$ \\
\hline $\mathbf{3}$ & DPPH $(\%)$ & $29.05 \pm 3.97$ \\
\hline $\mathbf{4}$ & Hydrogen peroxide $\left(\mathrm{H}_{2} \mathrm{O}_{2}\right)(\%)$ & $45.25 \pm 15.23$ \\
\hline $\mathbf{5}$ & Hydroxyl radical $\mathrm{OH}-(\%)$ & $86.51 \pm 23.55$ \\
\hline
\end{tabular}

\section{Values are expressed as mean \pm standard deviation of 3 replicates}

The in vitro antioxidant activity of Gymnema sylvestre methanolic leaf extract shows that the level of SOD was significantly decreased in $\mathrm{H}_{2} \mathrm{O}_{2}$ induced and $\mathrm{H}_{2} \mathrm{O}_{2}+$ extract induced when compared with normal control; the level of GSH was significantly increased in $\mathrm{H}_{2} \mathrm{O}_{2}$ induced and significantly decreased in extract induced and $\mathrm{H}_{2} \mathrm{O}_{2}+$ extract induced when compared with normal control, GSH was also significantly decreased in extract induced and $\mathrm{H}_{2} \mathrm{O}_{2}$ +extract induced when compared with $\mathrm{H}_{2} \mathrm{O}_{2}$ induced control; GSH was also increased in $\mathrm{H}_{2} \mathrm{O}_{2}$ +extract induced when compared with extract induced control.

Table 6: In vitro antioxidant activity and Lipid Peroxidation (LPO) Effect of Gymnema sylvestre methanolic leaf extract In Rabbit Liver Slices

\begin{tabular}{|c|c|c|c|c|}
\hline Composition & SOD U/ml & CAT U/ml & GSH mg/ml & $\begin{array}{l}\text { MDA } \\
\text { mmolTBARS }\end{array}$ \\
\hline Group I(Control) & $2.13 \pm 0.03$ & $27.523 \pm 4.00$ & $0.05 \pm 0.00$ & $17.05 \pm 8.55$ \\
\hline $\begin{array}{l}\text { Group II }\left(\mathrm{H}_{2} \mathrm{O}_{2}\right. \\
\text { induced })\end{array}$ & $2.04 \pm 0.02^{\mathrm{a}}$ & $64.22 \pm 15.86$ & $0.07 \pm 0.01^{\mathrm{a}}$ & $25.39 \pm 7.47^{\mathrm{b}}$ \\
\hline $\begin{array}{l}\text { Group } \\
\text { III }\left(\mathrm{H}_{2} \mathrm{O}_{2}+\text { extract }\right)\end{array}$ & $2.07 \pm 0.01^{\mathrm{a}}$ & $13.76 \pm 1.240$ & $0.04 \pm 0.00^{\mathrm{a}, \mathrm{b}, \mathrm{c}}$ & $18.44 \pm 2.15^{\mathrm{b}}$ \\
\hline
\end{tabular}


Values are expressed as mean \pm standard deviation of 3 replicates, those bearing different superscript a,b, and c under the same column respectively are significant with controls, group 1, 2, and 3 using students t-test at $\mathrm{p}<0.05, \mathrm{~N}=3$.

The alpha-amylase inhibitory activity of Gymnema sylvestre shows dose dependency with highest activity in the concentration of $20 \mathrm{mg} / \mathrm{ml}$, the $\mathrm{IC}_{50}$ value was found to be lower than standard (acarbose) as shown in table 7.

Table 7: Alpha amylase inhibitory effect of Gymnema sylvestre methanolic leaf extract

\begin{tabular}{llllll}
\hline Composition & $\mathbf{4 m g} / \mathbf{c m}^{\mathbf{3}}$ & $\mathbf{8 m g} / \mathbf{~ c m}^{\mathbf{3}}$ & $\mathbf{1 5} \mathbf{m g} / \mathbf{c m}^{\mathbf{3}}$ & $\mathbf{2 0} \mathbf{m g} / \mathbf{c m}^{\mathbf{3}}$ & $\mathbf{I C 5 0}$ \\
\hline Control & $9.1 \pm 1.56$ & $29.35 \pm 0.49$ & $58.05 \pm 0.71$ & $75.10 \pm 4.1$ & $200.05 \pm 7.16$ \\
Test & $17.65 \pm 0.78^{\mathrm{a}}$ & $29.55 \pm 0.78$ & $47.15 \pm 1.63^{\mathrm{a}}$ & $84.35 \pm 0.35$ & $195.3 \pm 4.40$
\end{tabular}

Values are expressed as mean \pm standard deviation of 3 replicates, those bearing superscript a, are significant with controls.

The alpha-glucosidase inhibitory activity of Gymnema sylvestre shows highest activity in the concentration of $20 \mathrm{mg} / \mathrm{cm}^{3}$, the $\mathrm{IC}_{50}$ value was found to be lower than standard (acarbose) as shown in table 8 .

Table 8: Alpha glucosidase inhibitory effect of Gymnema sylvestre methanolic leaf extract.

\begin{tabular}{llllll}
\hline Composition & $\mathbf{4 m g} / \mathbf{c m}^{\mathbf{3}}$ & $\mathbf{8 m g} / \mathbf{c m}^{\mathbf{3}}$ & $\mathbf{1 5 m g} / \mathbf{c m}^{\mathbf{3}}$ & $\mathbf{2 0} \mathbf{m g} / \mathbf{c m}^{\mathbf{3}}$ & $\mathbf{I C 5 0}$ \\
\hline Control & $31 \pm 0.42$ & $46.15 \pm 4.46$ & $58.7 \pm 1.84$ & $88.1 \pm 0.28$ & $189.52 \pm 0.46$ \\
Test & $33.6 \pm 0.57^{\mathrm{a}}$ & $40.15 \pm 0.07$ & $81 \pm 0.424^{\mathrm{a}}$ & $81.1 \pm 0^{\mathrm{a}}$ & $182.26 \pm 1.05^{\mathrm{a}}$
\end{tabular}

Values are expressed as mean \pm standard deviation of 3 replicates, those bearing superscript a, are significant with controls.

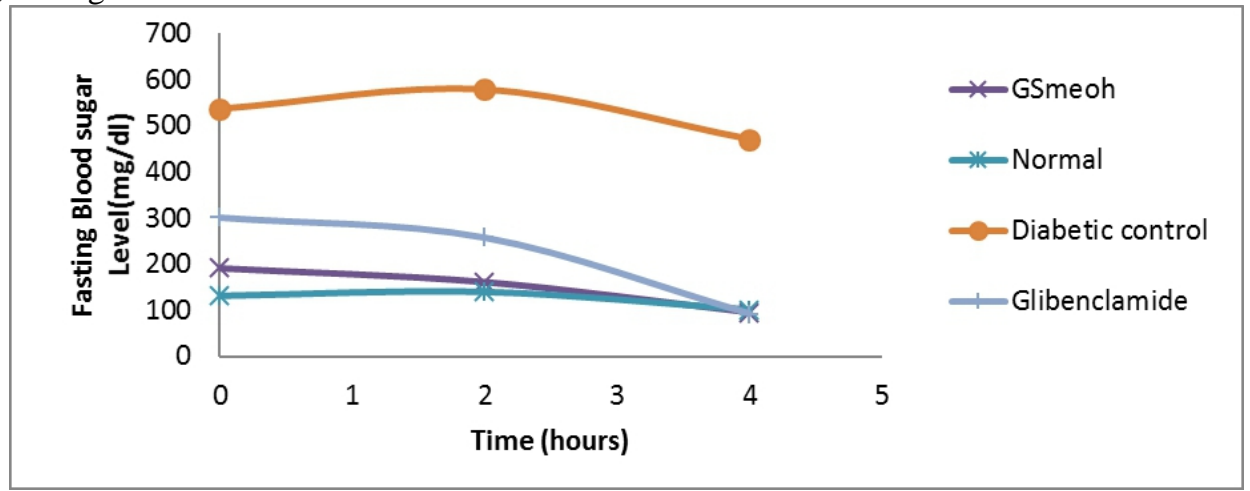

Fig. 1: Mean Fasting Blood sugar Level (mg/dl) of Alloxan-induced Diabetic Mice

\section{Discussion}

Administered G. sylvestre methanolic leaf extracts

The quantitative phytochemical analysis of GSMLE was rich in alkaloids, flavonoids, tannins and saponins with $15.43 \%, 0.61 \%, 12.12 \%$ and $62.98 \%$ respectively. This result shows that Gymnema sylvestre is richer in saponin among the phytochemicals present. Phytochemicals are known to show medicinal activity as well as exhibiting physiological activity (Lachman et al., 1989). Bioflavonoids, phenolic acids, ascorbic acid and tocopherols are well known subclass of phytochemical principles with 
antioxidant properties and are used for the treatment of various ailments (Barnes, 2001).

The HPLC analytical chromatogram of the GSMLE was compared with that of standard catechol, gallic acid, quercetin, saponin white and resorcinol. Chromatogram peaks, retention times and molecular features comparison revealed that the polyphenols observed in GSMLE were resorcinol, saponin white or catechol (Table 3). These compounds are known to have therapeutic potentialities (Aiyegoro and Okoh, 2010; Eleazu and Okafor, 2012; Saidi et al., 2016). Thus, the presence of these compounds might be responsible for the biological activities of GSMLE observed in this study.

. The total phenolics content in GSMLE was $6.63 \mu \mathrm{g} / \mathrm{ml}$ of Catechol equivalent. These diverse groups of compounds have received much attention as potential natural antioxidants. The antioxidant activity of the plant extract is mainly due to presence of phenolic compounds due to their redox properties, hydrogen donor capacity and singlet oxygen quenching (Hatano et al., 1989). Various mechanisms might contribute to their antihyperglycemic property, these including: inhibition of carbohydrate digestion (by inhibiting alpha amylase and alpha glucosidase) and glucose absorption in the intestine; stimulation of insulin secretion from pancreatic$\beta$-cells, modulation of signaling pathways and gene expression among others (Bahadoran et al., 2013). Although the total flavonoids content was relatively small, relative to the phenolic contents, it may also contribute to the antioxidative properties of the plant extract as suggested by Saggu et al. (2014). Due to their redox abilities; these compounds contribute to the total antioxidant activities of GSMLE. The mechanisms of their antioxidant activity in cells; are neutralizing free radicals and preventing decomposition of hydroperoxides into free radicals that subsequently damage cells ( $\mathrm{Li}$ et al., 2009) and hence, have potential in prevention and management of diabetics(Kim et al., 2016).

DPPH assay is generally used method to evaluate the free radical scavenging power of medicinal plants. The DPPH radical involves a hydrogen atom transfer process (Kaviarasan et al., 2007). The result of DPPH scavenging activity indicates that the GSMLE contain compounds that are capable of donating hydrogen to a free radical in order to remove odd electron which is responsible for radical's reactivity. Hydroxyl radicals are highly strong reactive oxygen species, and there is no specific enzyme defense against them in human body (Liu et al., 2005). Hydrogen peroxide itself is not very reactive, but it may induce hydroxyl radicals, which would result in great damage to cells (Halliwell, 1991). The extract has been found to possess relatively good reducing power and DPPH radical scavenging property. 
Lipid peroxidation is one of the characteristic features of diabetes mellitus. In diabetes, red blood cells were more susceptible to lipid peroxidation. Measurement of plasma thiobarbituric acid reactive substances (TBARS) was used as an index of lipid peroxidation and it helps to assess the extent of tissue damage (Gutteridege, 1995). Several studies have reported an increase in TBARS and hydrogen peroxides in plasma, liver and kidney in experimental diabetes mellitus (Ananthan et al., 2004). This study also shows an increase in TBARS level in an experimental rabbit liver in group II i.e the one induced with $\mathrm{H}_{2} \mathrm{O}_{2}$ (oxidative stress) and a subsequent decrease in treatment with GSMLE. This shows that GSMLE is also potent antioxidants that inhibit lipid peroxidation. It has been reported that feeding G.sylvestre extract to diabetic rats decreased lipid peroxidation levels by $31.7 \%$ in serum, $9.9 \%$ in liver and $9.1 \%$ in kidney (Kang et al., 2012).

The reducing tendency of a plant extracts may serve as a vital indicator of its potential antioxidant activity. Glutathione (GSH) is a tripeptide, non protein thiol intracellular antioxidant and protects or coordinates the cellular defense system from adverse effects of lipid peroxidation. Superoxide dismutase (SOD) protects the membrane from oxygen free radicals by catalyzing the removal of superoxide radical, which damage the membrane and biological structures. Catalase was shown to be responsible for the detoxification of $\mathrm{H}_{2} \mathrm{O}_{2}$ (Mahboob et al., 2005). In the present study we observed decreased SOD, catalase and GSH activities in GSMLE as compared to control. A significant decrease was observed in SOD compared to the control, while catalase and GSH were not significant with their controls and this slight depletion in the levels of the enzymes could be attributed in their involvement in the scavenging of $\mathrm{H}_{2} \mathrm{O}_{2}$. The increased generation of lipid peroxidation products induces compensatory changes expressed by enhanced utilization of antioxidants and decrease serum activity of antioxidant enzymes and non-enzymatic antioxidants.

A significant decrease in activity in GSMLE liver slices was also observed in group I and III for SOD, and group II and III for GSH, while a significant increase was observed in group II for GSH. There was no significant activity in catalase. This shows that Gymnema sylvestre is a good source of antioxidants, which may play vital role in inhibition of lipid peroxidation or in protection against cellular damage by free radicals.

Alpha - glucosidase and $\alpha$-amylase enzymes play a major role in type 2 diabetic patients and borderline patients (Ali et al., 2006). In this study, concentrations of $4 \mathrm{mg} / \mathrm{ml}$ and $15 \mathrm{mg} / \mathrm{ml}$ of plant extract showed significant inhibitory activity with the control (acarbose) for alpha amylase; also at the concentration of 4,15 and $20 \mathrm{mg} / \mathrm{ml}$ of plant extract shows significant activity with the controls (acarbose) for alpha glucosidase. The $\mathrm{IC}_{50}$ value for alpha glucosidase $(182.26 \pm 1.05 \mu \mathrm{g} / \mathrm{ml})$ was also shown to be 
significantly lower with acarbose $(189.52 \pm 0.46 \mu \mathrm{g} / \mathrm{ml})$ and alpha-amylase was more potent than the arcarbose with $\mathrm{IC}_{50}$ of $195.3 \pm 4.40$ and $200.05 \pm 7.16$ respectively.. This means that GSMLE is more potent than acarbose. The inhibitors of alpha amylases are better suppressor of postprandial glyacemia because it may not lead to abnormal accumulation of maltose; which causes abdominal pain, flatulence, diarrhea etc (Uchida et al., 1999). The inhibiting activities of these enzymes could be attributed to the phytochemical components detected in GSMLE such as polyphenols, flavonoids and glycosides as previously reported (Jung et al. 2006; Eleazu and Okafor, 2012). This findings were further consolidated by in vivo study that demonstrated significant decrease in blood glucose of alloxan-induced experimental animal when administered with extract after two (2) and four (4) hours (Fig. 1).

\section{Conclusion}

The study conducted revealed that methanolic leaf extract of Gymnema sylvestre exhibited potent in vitro antioxidant activities and antilipid peroxidation due to the presence of phytochemical constituents like saponins, flavonoids, and phenolic compounds like catechol and resorcinol and can be used as an alternative inhibitor of alpha amylase and alpha glucosidase enzymes in the management of non-insulin dependent diabetes mellitus.

\section{References:}

1. Ali, H., Houghton, P.J. and Soumyanath, A. (2006). $\alpha$-Amylase inhibitory activity of some Malaysian plants used to treat diabetes; with particular reference to Phyllanthus amarus.J. Ethnopharmacol., 107: 449-455.

2. Aiyegoro, O.A. and Okoh, A.I. (2010).Preliminary phytochemical screening and In vitro antioxidant activities of the aqueous extract of Helichrysum longifolium DC. BMC Complementary and Alternative Med.10:21.

3. Ananthan, R., Latha, M., Pari, L., Baskar, C. and Narmatha, V. (2004). Modulatory effects of Gymnema montanum leaf extract on alloxan induced oxidative stress in wistar rats Nutrition, 20: 280-285.

4. Bahadoran,Z.,Mirmiran,P.,andAzizi,F.(2013).Dietary polyphenols as potential nutraceuticals in management of diabetes: a review. $J$. Diabetes Metab.Disord.12,1-9.doi:10.1186/2251-6581-12-43.

5. Barnes, S. (2001). Role of phytochemicals in prevention and treatment of prostate cancer. Epidemiol. Rev. 23(1):201-205.

6. Bischoff, H. (1994). Pharmacology of alpha-glucosidase inhibition. Eur. J. Clin. Invest; 24: 3-10. 
7. Cameron, G.R, Milton, R.F. and Allen, J.W. (1943). Measurement of flavonoids in plant samples. Lancet, p. 179.

8. Chakrabarti, R. and Rajagopalan, R. (2002). Diabetes and insulin resistance associated disorders: Disease and the therapy. Curr. Sci; 83: 1533-1538.

9. EFSA (2015). Food Supplements| European Food Safety Authority. Food Suppl. Availableat: http://www.efsa.europa.eu/en/topics/topic/supplements [accessed November, 2015].

10. Eleazu, C.O. and Okafor, P.N.(2012). Antioxidant effect of unripe Plantain (Musa paradisiacae) on oxidative stress in alloxan-induced diabetic rabbits. Int. J. of Med. and Biomed. Res. 1(3):1-10.

11. Elizabeth, K. and Rao, M.W.A. (1990). Oxygen radical scavenging activity of Curcumin, Int. J. Pharm., 58, 237-240.

12. Fred-Jaiyesimi, A., Kio, A. and Richard, W. (2009). Alpha-Amylase inhibitory effect of 3 $\beta$-olean-12-en-3-yl (9Z)-hexadec-9-enoate isolated from Spondias mombin leaf. Food Chem; 116: 285-288.

13. Goycheva, P., Gadjeva, V., Popov, B., (2006). Oxidative stress and its complications in diabetes mellitus. Trakia J. Sci. 4 (1): 1-8.

14. Grover, J.K., Yadav, S. and Vats, V. (2002). Medicinal plants of India with anti-diabetic potential. J. Ethnopharmacol; 81: 81-100.

15. Gupta, M., Sasmal, S., Majumdar, S. and Mukherjee, A. (2012). HPLC Profiles of Standard Phenolic Compounds Present in Medicinal Plants. Int. J. of Pharmacog. and Phytochem. Res; 4(3): 162-167.

16. Gutteridge, J.M.C. (1995). Lipid peroxidation and antioxidants as biomarkers of tissue damage. Clin. Chem; 14: 1819-1828.

17. Halliwell, B. (1991). Reactive oxygen species in living systems: source, biochemistry, and role in human disease. Am. J. of Med. 91; 14-22.

18. Hatano, T., Edamatsu, R. and Mori, A. (1989). Effects of interaction of tannins with coexisting substances. Chem. Pharm. Bull, 37: 20162021.

19. Iwai, K. (2008). Antidiabetic and antioxidant effects of polyphenols in brown algae Ecklonia stolonifera in genetically diabetic KK-A(y) mice. Plant Foods Hum. Nutr., 63: 163-169.

20. Jarald, E., Joshi, S.B. and Jain, D.C. (2008). Diabetes and herbal medicines. Iranian J. Pharmacol. Ther. 7 (1): 97-106.

21. Jin, L., Xue, H.Y., Jin, L.J., Li, S.Y. and Xu, Y.P. (2008). Antioxidant and pancreas protective effect of aucubin on rats with streptozotocin-induced diabetes. Eur. J. Pharmacol., 582: 162-167. 
22. Jung, M., Park, M., Chul, H.L., Kang, Y., Seok-Kang, E. and KiKim, S. (2006). Antidiabetic agents from medicinal plants. Curr Med. Chem. 13: 1203-1218.

23. Kamble,B.,Gupta,A.,Moothedath,I.,Khatal,L.,Janrao,S., Jadhav, A., et al.(2016).Effects of Gymnema sylvestre extract on the pharmacokinetics and pharmacodynamics of glimepiride in streptozotocin induced diabetic rats. Chem.Biol.Interact. 245,30-38.

24. Kang, M., Lee, M., Choi, M., Min, K.S., Shibamoto, T. (2012). Hypoglycemic activity of $G$. sylvestre extracts on oxidative stress and antioxidant status diabetic rats.J.Agric.FoodChem.60 (10),25172524.

25. Kaviarasan, S., Naik, G.H., Gangabhagirathi, R., Anuradha, C.V. and Priyadarsini, K.I. (2007). In vitro studies on antiradical and antioxidant activities of fenugreek (Trigonella foenumgraecum) seeds. Food Chem.103, 31-37.

26. Khan, V., Najmi, A.K., Akhtar, M., Aqil, M., Mujeeb, M. and Pillai, K.K. (2012). A pharmacological appraisal of medicinal plants with antidiabetic potential. J. Pharm. Bioall. Sci. 4 (1): 27-42.

27. Kakkar, R., Mantha, S., Radhi, J., Prasad, K. and Karla, J. (1984) Antioxidant defense system in diabetic kidney. Life Sci. 60:667-679.

28. Kim, J.S., Kwon, C.S. and Son, K.H. (2000). Inhibition of alphaglucosidase and amylase by luteolin, a flavonoid. Biosci Biotech Biochem, 64(11):2458-61.

29. Kim, G.N., Shin, J.G. and Jang, H.D. (2009). Antioxidant and antidiabetic activity of Dangyuja (Citrus grandis Osbeck) extract treated with Aspergillus saitoi. Food Chem; 117: 35-41.

30. Kim,Y., Keogh, J.B., and Clifton, P.M.(2016).Polyphenols and glycemic control. Nutrients 8:17.

31. Kimmel, B. and Inzucchi, S. (2005). Oral agents for type 2 diabetes: An update. Clin. Diabetes; 23: 64-76.

32. Klein, H.J. and Bayne, K.A. (2007). Establishing a culture of care, conscience, and responsibility: Addressing the improvement of scientific discovery and animal welfare through science-based performance standards. ILAR J. 48:3-11.

33. Lachman, L., Lieberman, H.A. and Kanig, J. (1989). The Theory and Practice of Industrial pharmacy, Edn 3, Varghese publishing house, New York; 293-373.

34. Li H., Hao Z., Wang X., Huang L., Li J.(2009). Antioxidant activities of extracts and fractions from Lysimachia foenum-graecum Hance. Bioresour. Technol. 100:970-974.

35. Li,Y.,Zheng,M.,Zhai,X.,Huang,Y.,Khalid,A.,Malik,A.,etal.(2015).Eff ect of-Gymnema sylvestre, citrullus colocynthis and Artemisia 
absinthium on blood glucose and lipid in diabetic human. Acta Pol. Pharm.72,981-985.

36. Lim, S.S., Vos, T., Flaxman, A.D., Danaei, G., Shibuya, K. and Adair-Rohani. (2012). A comparative risk assessment of burden of disease and injury attributable to 67 risk factors and risk factor clusters in 21 regions, (1990-2010): a systematic analysis for the Global Burden of Disease Study (2010). Lancet; 380(9859): 22242260.

37. Liu, C.Z., Yu, J.C., Zhang, X.Z., Wang, T. and Han, J.X. (2005). On changes of activity of antioxidases in hippocampus of rats with multiinfarct dementia and the intervention effects of acupuncture. China Journal of Traditional Chinese Medicine and Pharmacy; 20: 724726.

38. Luck, H. (1974). Catalase in methods of enzymatic analysis, Vol II, edited by J Bergmeyer and M Grabi, Academic press, New York. Pp. 885-890.

39. Mahboob, M., Rahman, M.F. and Grover, P. (2005). Serum lipid peroxidation and antioxidant enzyme levels in male and female diabetic patients. Singapore. Med. J., 46: 322-324.

40. Mallick, C.P. and Singh, M.B. (1980). Plant enzymology and Histoenzymology. Kalyani publishers, New Delhi P. 286.

41. Mandal, P., Misra, T.K. and Ghosal, M. (2009). Free-radical scavenging activity and phytochemical analysis in the leaf and stem of Drymaria diandra Blume. Int. J. Integr. Biol., 7: 80-84.

42. Maritim, A.C., Sanders, R.A., and Watkins, J.B. (2003). Diabetes oxidative stress and antioxidants. A Review. J. Biochem. Mol. Toxicol., 17:24-38.

43. Maxwell, S.R.J. (1995). Prospects for the use of antioxidant therapies Drugs. 49: 345-361.

44. Mensor, L. L., Menezes, F. S., Leitao, G. G.., Reis, A. S., Dos Santos, T. C., Coube, C. S. and Leitao S.G.(2001). Screaning of Gymneme sylvestre plant extracts for antioxidant activity by the use of DPPH free radical method. Phytoter. Res. 15: 127-130.

45. Moron, M.S., Depierre, J.W. and Manner, V. B.(1979). Levels of glutathione, glutathione reductase and glutathione-s-transferase activities in rat lungs and liver. Biochem. Biophys. Acta. 582:67-72.

46. Nichans, W.G and Samuelson, D. (1968). Formation of malondialdihyde from phospho lipid arachidonate during microsomal lipid peroxidation. Eur. J. Biochem. 6: 126-130.

47. NIH (1996). NIH Guide for the Care and use of Laboratory Animals. NIH Publication, No. 23-83. 
48. Odegaard, A. O., Jacobs, D. R., Sanchez, O. A., Goff, D. C., Reiner, A. P. and Gross, M. D. (2016)“'Oxidative stress, inflammation, endothelial dysfunction and incidence of type 2 diabetes," Cardiovascular Diabetology, 15(1):1-12.

49. OECD (2006). Repeated Dose 28-day oral Toxicity Study in Rodents; Updated with Parameters for endocrine effects. http://www.oecd.org/dataoecd.

50. Petrovska, B.B.(2012). Historical review of medicinal plants usage. Pharmacogn Rev.6:1-5.

51. Pham-Huy, L.A., He, H. and Pham-Huyc, C. (2008). Free radicals, antioxidants in disease and health. Int. J. Biomed. Sci., 4: 89-96.

52. Ruch, R J., Cheng S J. and Klainig J E. (1989). Prevention of cytotoxicity and inhibition of intracellular communication by antioxidant catechins isolated from chinase green tea. Carcinogen. 10: 1003-1008.

53. Saggu S., Sakeran M.I., Zidan N., Tousson E., Mohan A., Rehman H. (2014). Ameliorating effect of chicory (Chichorium intybus L.) fruit extract against 4-tert-octylphenol induced liver injury and oxidative stress in male rats. Food Chem. Toxicol. 72C:138-146.

54. Saidi, N., Elmsellem, H., Ramdani, M., Yousfi, F., Rmili, R., Azzaoui, K., Aouniti, A. and Chahboun, N. (2016). A Moroccan Opuntia Ficus indica methanolic flowers extract as an eco-friendly antioxidant and anti-corrosion for mild steel in $1 \mathrm{M} \mathrm{HCl}$. J. Mater. Environ. Sci. 7 (11): 4105-4115.

55. Shori,A. B. (2015).Screening of antidiabetic and antioxidant activities of medicinal Plants. J.Integr.Med.13,297-305.

56. Sofowara, A. (1993). Medicinal Plant and Traditional Medicine in Africa. New York: John Wiley and sons. Pp. 191-289.

57. Tarling, C.A., Woods, K., Zhang, R., Brastianos, H.C., Brayer, G.D., Andersen, R.J. and Withers, S.G. (2008).The search for novel human pancreatic $\alpha$-amylase inhibitors: high-throughput screening of terrestrial and marine natural product extracts. Chem. Bio. Chem; 9: 433-438.

58. Trease, G.E. and Evans, W.C. (2002). Pharmacognosy. 15th Ed. Saunders Publishers, London. pp. 42-44, 221-229, 246-249, 304-306, 331-332, 391-393.

59. Uchida, R., Nasu, A., Tokutake, S., Tobe, K. and Yamaji, N.(1999). Synthesis of New N-containing maltooligosaccharrides, alphaamylase inhibitors and biological activities. Chem.Pharm. Bull. 47: 187-193.

60. Vishnoi, N R. (1979). Advanced Practical Chemistry. Ghaziabad India: yikas publication House, pvt ltd: Pp. 447-449. 
61. Vos,T.,Flaxman,A.D.,Naghavi,M.,Lozano,R.,Michaud,C.,Ezzati,M.,e $\mathrm{t}$ al.(2012).Years lived with disability (YLDs) for 1160 sequelae of 289 diseases and injuries 1990-2010: a systematic analysis for the global burden of disease study 2010. Lancet 380,2163-2196.

62. Yanarday, R. and Colae, H.(1998). Effects of ghand (Beta vulgaris L.varcicla) on blood glucose level in normal and alloxan-induced diabetic rabbit. J. Ethanorpharm.4:309-311.

63. Yao, Y., Sang, W., Zhou, M. and Ren, G. (2010). Antioxidant and $\alpha-$ glucosidase inhibitory activity of colored grains in China. J. of Agric. Food Chem., 58: 770-774. 